\title{
Research on Marxist Theory Education in the Vision of Cultural Confidence
}

\author{
Guohong Wang, Kena Wang* \\ Qiqihar Medical University, Academy of Marxism, Qiqihar City, Heilongjiang Province, 161006
}

Keywords: cultural self-confidence; Marxism; theoretical education; socialist cultural construction

\begin{abstract}
At present, our country's cultural self-confidence belongs to people's confidence in the advanced culture possessed by the current socialist state. On the one hand, it reflects people's rational examination of traditional culture, and on the other hand, it highlights the use of reference and inclusive world culture. In the prosperity and development of our country's socialist culture, Marxist theoretical education has played an important role. To deepen and consolidate the ideological guiding position, it is essential to scientifically and effectively implement the content of studying cultural self-confidence in Marxist theoretical education. This paper rigorously analyzes and expounds the Marxist theory education in the field of cultural self-confidence vision, aiming at realizing the people's high level of cultural self-confidence, and then significantly promoting the effectiveness and forward development of Marxist theory education.
\end{abstract}

\section{Introduction}

In our country's cultural construction, the main theme is cultural self-confidence, self-consciousness, and self-improvement. However, regarding the understanding of cultural self-confidence, there are widespread phenomena in China such as pursuing western culture, respecting the sages of the sages, and despising the Marxist culture. Moreover, some people with different academic cognitions have marginalized Marxism, which is completely contrary to the essence of cultural self-confidence. In view of this situation, in the current construction of socialist culture in our country, we must pay attention to improving the self-confidence of Marxist theoretical education and persist in embodying it in the whole party and the whole society.

\section{The Connotation of Cultural Self-confidence and Marxist Theoretical Education}

To carry out socialist cultural construction and implement Marxist theory education in the whole party and society as a whole is a major manifestation of cultural self-confidence and cultural awareness. The Communist Party of China has always paid high attention to the cause of cultural construction. At many meetings, it has formulated major tasks concerning building a strong socialist cultural country. Among them, the connotation of Marxist theory education proposed is: It is a key component of the content of socialist cultural construction. During the continuous development of a strong socialist culture, Marxist theory education must be carried out. Marxist theoretical education should be built under the great environment of socialist cultural construction in order to effectively innovate and develop.

The cultural self-confidence proposed by China is a socialist culture with Chinese characteristics and is self-confident. It is characterized by the combination of the basic principles of Marxism in China's actual development. The important foundation for cultural self-confidence is the successful realization of revolution, construction reform and innovation, while conducting prudent analysis and inheriting outstanding values. The self-confidence of socialism with Chinese characteristics is derived from the self-confidence of Marxist theory. The self-confidence in Marxist theory is an important foundation for the self-confidence of Marxist theoretical education. Since the birth of Marxism, our party has attached great importance to education and propaganda during the revolution and construction period, and has constructed a scientific and effective Marxist theoretical education. At present, Marxist theory education has been implemented into the classroom, teaching materials, the branch and the mind, and various levels of cadre schools, academies of social 
sciences, colleges and universities, and party schools have all adopted Marxism as a key learning course. This fully shows that its important position in development. In addition, Marxist theoretical education based on cultural self-confidence is an important opportunity provided by the era forward development, but in practice, there are obvious problems such as insufficient self-confidence. Such as: there is Marxism outdated theory and useless theory, Marxist narrow-minded theory, etc., for Marxist theory education does not form a high degree of theoretical self-confidence, questioning often accompanied by unconditional affirmation and so on. Therefore, in order to effectively promote the self-confidence of Marxist theoretical education, it is necessary to provide support with scientific principles, and to establish sufficient and meticulous logical arguments, establish comparisons and integration in Chinese traditional culture, compare and criticize the western bourgeois culture, to determine the truth and scientific nature of Marxist culture in development practice.

\section{Clarifying Marxist Theoretical Education Self-confidence in Cultural Traits Analysis}

The self-confidence of Marxist theoretical education belongs to the educational and cultural form. However, in terms of cultural characteristics and connotations, it does not have a high degree of recognition in educational practice. To clarify Marxist theoretical education self-confidence, it should be sorted out with scientific principles.

From the perspective of class nature, Marxism has a clear political position. That is to say, taking the masses of the people as their fundamental interests, human liberation and the free development of people as their main basic positions, this gives them an obvious class character. In terms of science, people generally believe that Marxist theory education is subjective and narrow, which is a cognitive misunderstanding. Dialectical materialism and historical materialism, on the one hand, are proletarian world views and methodologies. On the other hand, they can fundamentally reveal scientifically the laws of human society and the development of the natural world and provide important methods for human understanding of the world. At the same time, the scientific nature of Marxist theoretical education is also embodied in that, on the one hand, it belongs to the theory of communication science; on the other hand, it also belongs to the science communication theory, and it is not a theoretical dogmatic development.

The cultural value of Marxist theory is relatively clear. Marxist theoretical education is not only a grand narrative, but also pays attention to individual care, and exerts the effect of instilling ideology and cultural communication activities. These include the cultural forms, the inheritance of excellent traditional culture, the maintenance of mainstream culture, the criticism of heterogeneous culture, and the integration of multiple cultures. The dissemination of Marxist theoretical education is an important core culture as well as political culture and mainstream culture in China. The current study and practice of Marxism, Party members, and members of society all accept the mainstream political culture. Under such an environment, immersing and nurturing people, shaping the people's ideological and moral qualities and ideals and beliefs is a way to promote socialist culture.

During the implementation of Marxist theoretical education, its development and dissemination of scientific and cultural knowledge, Marxist theory education actively guides people toward the social life that is essentially for practice. From a practical point of view, on the one hand, it is involved in the formation of the Marxist theoretical system. On the other hand, Marx has also actively participated in the proletarian revolutionary cause and made important contributions to liberating the proletariat and liberating mankind. . China's education in Marxist theory has always attached importance to the actual needs of Chinese society and revolution, construction, and reform. In some anti-Marxist and non-Marxist trends of thought, it is also aimed at how to transform Chinese society and social issues in China. In the education of Marxist theory, through the organic combination of its theoretical and practical aspects, Marxist theory has become more prominent in its superb vitality.

Marxist theory education has a high degree of professionalism in terms of knowledge systems, educational content, and academic development. The unity of Marxist theoretical education and generality is to regard scientific theory as important core content and achieve the goal of human 
emancipation. Through Marxist theoretical education, people are encouraged to form a correct world view, outlook on life, values, and a sound personality. The people pursue the ideals of truth, goodness and beauty, and Marxism-related educational content is the real need to provide for the development of every member of society.

\section{Heighten the Self-confidence of Marxist Theoretical Education through the Comparison of Cultures}

All theories can not only achieve ideal development through simple application, but must be thoroughly analyzed and merged in order to achieve deep-rooted results. Marxism and the history of Chinese civilization are interlinked, harmonious, and mutually reinforcing. At the initial stage of its establishment, the observation of the Chinese issue is based on the perspective of world history. The content of Marxism studies is the development law of human society and thinking and the natural world. The content of Chinese culture studies is based on the height of philosophy and analyzes society, life, and the nature of the universe. The two parties share the same thoughts.

Marxism is a socialist ideology. Compared with capitalist ideology, Marxism has obvious differences. However, to treat capitalist culture, we should uphold the notion that Marxist theory should abandon itself. The critique of capitalist theory is on the one hand the ideological field struggle and on the other hand the cultural rationality and spiritual struggle. We should have the courage to directly confront the erosion and impact of multiculturalism. The handling of cultural contradictions can be based on rational criticism and rigorous argumentation. Ultimately, we can grasp the leadership and development direction of cultural construction and political construction.

\section{The Important Ways to Adhere to Marxist Theory Education Confidence in Cultural Development}

In the continuous development of the society, the cultural connotation of Marxism is constantly progressing and developing. Under such circumstances, Marxist theoretical education self-confidence has a more important position and role. It is necessary to strengthen the self-confidence of Marxist theory education. . A great deal of practice has proved that when Marxist theoretical education is to a large extent analyzed on social realities, its cohesiveness, influence, and vitality are even higher. During the education of Marxist theory, it is necessary to fully consider the development and changes in the real national conditions, the world conditions, and other aspects, and closely contact the hot and difficult issues of the society to conduct theoretical education. At the same time, it is necessary to conduct in-depth analysis and research on social reality issues based on the frontier content of the subject, highlighting the novelty and the characteristics of the times. In addition, accompanied by the development of Marxist theoretical education and cultural connotation, we must also make a beneficial absorption of traditional Chinese culture, popular culture and Western culture, and enjoy a rich ideological and cultural feast.

Marxist theory education is the organic interaction between the teacher and the teacher. The theoretical knowledge covered by Marxist theory is numerous and complex, including political, economic, cultural, military, social, and many other aspects. Therefore, Marxist theory educators have higher quality requirements, and the teacher must have a solid theoretical foundation. Moreover, it is necessary to continuously update the knowledge content with the progress and development of the times. Marxist theoretical education belongs to large cultural education and has a very crucial influence on the growth of educated people. Advocates should pay attention to the thoughts of the educators and their personal development, enhance the persuasiveness of education, and enable the educated to benefit for life.

There are two main paths, and the two are parallel. This is the method and popularization of the popularization of Marxist theoretical education. Through the application of popularization and popular methods, the corresponding cases and stories are used to describe and elucidate, and with the help of the power of culture and art, Marxist theory propaganda and education are carried out in education and pleasure. 
The cultural environment of Marxist theory education involves two aspects: the network virtual cultural environment and the actual cultural environment. Among them, the former needs further development and improvement, the application of various new carriers, the promotion of Marxist theory, the use of Marxism to guide the network culture, and the use of scientific network cultural resources. The latter's educational environment has not yet been fully formed and has not produced a good educational synergy. Therefore, the potential for development is enormous. The social environment should create more positive energy, carry out positive education, and establish an active Marxist theoretical education environment.

\section{Conclusion}

China's cultural self-confidence belongs to people's self-confidence in advanced culture. It not only shows people rationally examining traditional culture, but also shows powerful reference and tolerance of world culture. In the prosperity and development of our country's socialist culture, Marxist theoretical education has played an important role. It has deepened and consolidated its guiding position in ideology. It has become a general trend to implement and study the content of cultural self-confidence in Marxist theoretical education. Sex is self-evident. Therefore, in the current construction of socialist culture in our country, it is necessary to focus on elevating Marxist theoretical education self-confidence, embodying it in the overall work of the whole party and the whole society, and highly asserting Marxist theoretical education self-confidence.

\section{Acknowledgements}

Fund Project: 2017 Heilongjiang Provincial Department of Education higher education teaching reform project, ideological and political theory courses and "four into four letters" special teaching reform research project, "college ideological and political theory examination evaluation method and evaluation system", item number: SJGSY2017013.

\section{References}

[1] Wang Yonghe, Yang Hongxing. On the expansion of Marxist theory education in the network field [J]. School Party Building and Ideological Education, 2014(16): 4-6.

[2] Xiao Xianglong. Marxist Theoretical Education in the Perspective of Cultural Confidence [J]. Marxism Research, 2014(06): 130-136.

[3] Yang Xiaohui. Exploring the Cultural Context of Chinese Marxist Theory Education [J]. Marxism Research, 2015(06): 130-135+160.

[4] Fu Anling, Zhang Yaocan. Thinking Transformation of Marxist Theory Education in Big Data Era [J]. Academic Forum, 2016(10):169-175.

[5] Zhang Qing, Yang Yongqing. Axiological Analysis of Marxist Theoretical Education Function [J]. Hubei Social Sciences, 2013 (09): 5-9.

[6] Zhao Guozhen. On the important links and methods of Marxist theoretical education in universities [J]. Ideological and Theoretical Education, 2016(05):52-54.

[7] Wang Xisheng. The Legitimacy and Rationality of Marxist Theory Education in Universities [J]. Journal of Anhui Normal University (Humanities and Social Sciences), 2016(04):404-409. 